UDC 94(477.46):342.25

Tetiana KUZNETS,

orcid.org / 0000-0002-9282-110X

Doctor of Historical Sciences,

Professor of the Department of History of Ukraine Pavlo Tychyna Uman State Pedagogical University

(Ukraine. Uman)

tetiana.kuznets@gmail.com

Anatolii KARASEVYCH,

orcid.org / 0000-0002-4261-6386

Candidate of Philosophical Sciences,

Professor of the Department of Philosophy and Social Disciplines Pavlo Tychyna Uman State Pedagogical University

(Ukraine. Uman)

karasevych@ukr.net

\title{
UMAN DISTRICT ZEMSTVO ON THE PAGES OF THE NEWSPAPER «KIEVLIANIN»: ELECTIONS, ECONOMIC ACTIVITY AND FINANCIAL OPPORTUNITIES
}

An appeal to the historical experience of local self-government bodies (zemstvos) functioning at the beginning of the XX century is determined by an ongoing administrative reform in Ukraine, in the course of which new government bodies - the consolidated territorial communities (CTC) are created. The aim of their formation is to optimise management, attract local financial reserves and initiatives to increase a socioeconomic development rate, improve a sociocultural sphere. The implementation of the reform cannot be safe from miscalculations and mistakes without taking into account a historical experience of zemstvos. Considering that the process of forming the elective land bodies in a «non-zemskyi» Kyiv province was covered on the pages of the periodical press, an important task is a retrospective analysis of newspaper publications about the election and activity of zemstvos. As a microhistorical approach makes it possible to study a single context, rather than the illustration of a general context, in this case the study of the activity of one district zemstvo encourages the establishment of anthropocentrism and enriches social history. Therefore, the task of a detailed and thorough study of historical experience necessitates the use of all kinds of historical sources.

Found publications about the Uman district zemstvo in the "Kievlianin» as one of the most widespread newspapers, form a complete picture about the election of zemskyi political figures and the main directions of their activity. The systematization of newspaper publications made it possible to present the election process on the basis of the law from March 14, 1911 in detail to find out the statistics of land ownings in Uman district, form a picture about the material possessions of the wealthy part of its residents, as the election law depended on the property qualification. The division of voters into two curiae (Russian and Polish) and a quantitative ratio of voters by nationality reflected a national policy of the Russian autocracy.

The newspaper "Kievlianin» publications about the activity of Uman electoral zemstvo show its innovative approaches to welcoming the initiative of the people, first of all - it supports a cooperative movement in Kyiv province, stimulating the development of handicraft and industrial production. Uman district zemstvo as of one of the largest in the province - emerges from the pages of "Kievlianin» as an effective tool attracting the intelligentsia and wealthy social strata to the economic and cultural rise in the region.

The conclusion of the article is the statement that the electoral zemstvos owing to their activity contributed to the revival of social life, stimulated the development of statistics, economics, culture, and also to some extent smoothed a social tension, because zemstvo taxes made it possible to direct money from rich strata to industrial and social spheres.

Key words: electoral zemstvo, Uman district zemstvo, Polish curia, agricultural cooperation, zemskyi tax, zemsky levies, Zemsky governing body.

Тетяна КУЗНЕЦЬ, orcid.org / 0000-0002-9282-110X доктор історичних наук, професор кафедри історії України Уманського державного педагогічного університету імені Павла Тичини 


\section{Анатолій КАРАСЕВИЧ, orcid.org / 0000-0002-4261-6386 \\ кандидат філософських наук, професор кафедри суспільних дисииплін Уманського державного педагогічного університету імені Павла Тичини \\ (Украӥна. Умань) \\ karasevych@ukr.net}

\section{УМАНСЬКЕ ПОВІТОВЕ ЗЕМСТВО НА СТОРІНКАХ ГАЗЕТИ «КИЕВЛЯНИН»: ВИБОРИ, ГОСПОДАРСЬКА ДІЯЛЬНІСТЬ ТА ФІНАНСОВІ МЖЛИВОСТІ}

Звернення до історичного досвіду функиіонування органів місчевого самоврядування початку ХХ ст. земств - зумовлене триваючою в Украӥні адміністративною реформою, у ході якої створюються нові органи управління - об'єднані територіальні громади (ОТГ). Метою їх формування є оптимізація управління, залучення місчевих резервів та ініціативи для підвищення темпів сочіально-економічного розвитку, удосконалення соиіокультурної сфери. А без урахування історичного досвіду діяльності земств реалізація реформи не може бути убезпечена від прорахунків та помилок. Зважаючи на те, щчо процес формування виборних земських органів у «неземській» Київькій губернії висвітлювався на сторінках періодичної преси, важливим завданням є ретроспективний аналіз газетних публікаиій про вибори та діяльність земств. А так як мікроісторичний підхід уможливлює дослідження одиночного, а не ілюстрацію загального контексту, то вивчення діяльності одного повітового земства сприяє утвердженню антропоцентризму та збагачує сочіальну історію. Тому завдання детального та досконалого вивчення історичного досвіду зумовлює необхідність використання усіх видів історичних джерел.

Виявлені у одній з найпоширеніших газет - «Киевлянин» - публікації про Уманське повітове земство створюють повне уявлення про вибори земських діячів та про основні напрямки їх діяльності. Систематизація газетних публікацій дала можливість детально представити процес виборів на основі закону від 14 березня 1911 р., зокрема з'ясувати статистику землеволодінь в Уманському повіті, скласти уявлення про матеріальні статки заможної частини його мешканців, так як виборче право залежало від майнового иензу. Поділ вибориів на дві курії (російську та польську) та кількісне співвідношення вибориів за національною ознакою рельєфніше увиразнив національну політику російського самодержавства.

Публікації газети «Киевлянин» про діяльність Уманського виборного земства показують його новаторські підходи до підтримки ініціативи народу, в першу чергу - ие підтримка кооперативного руху в Київській губернії, стимулювання розвитку кустарного та промислового виробництва. Земство одного $з$ найбільших в губернії повітів - Уманського постає зі сторінок «Киевлянина» як ефективний важіль залучення інтелігенції та заможних суспільних прошарків до економічного та культурного піднесення в краєві.

Загалом можна підсумувати, щзо виявлені у газеті «Киевлянин» та систематизовані публікації про Уманське повітове земство складають чітке уявлення про механізм земських виборів на основі закону від 14 березня 1911 року. Відомості про майновий иенз вибориів доповнюють статистику землеволодінь в Уманському повіті та дають уявлення про фінансові можливості деяких промислових підприємств, товариств, компаній. Поділ вибориів за майновим цуензом на три розряди та поділ за начіональною ознакою на російську та польську курії показують дискримінаційну сутність виборчого процесу. Навіть передбачена законом участь у виборах заможного селянства полишала найчисельніший суспільний стан можливості бути обраним до органів місиевого самоврядування: усього в «селянському» Уманському повіті до земських органів було обрано 13 осіб, а у «селянській» Київській губернї - 140 селян. Тобто, декларуючи свій всестановий характер, земства сприяли активізаиії діяльності ліберально налаштованих представників середнього класу та заможніх верств населення. Маючи державну підтримку та часткове фінансування своєї діяльності, земські органи методом земського податку формували власні кошти, які спрямовували на підтримку сільського господарства, стимулювання селянської кооперації, кустарного та промислового виробництва, на соціокультурні потреби населення.

Ключові слова: виборне земство, Уманське повітове земство, польська курія, сільськогосподарська кооперація, земський збір (податок), земські збори, земська управа. 
Problem formulation. In the context of the implementation of an administrative reform in Ukraine, presupposing the creation of consolidated territorial communities (CTC) with the election of their leadership, it is advisable to take into consideration the historical experience of forming local self-government bodies zemstvos. The history of zemstvos in the Right-Bank Ukraine dates back to 1890s. In 1903, a «simplified» zemstvo was implemented in the form of committees and administrations for agricultural affairs, the specificity of which was the appointment of composition and the authorities' concentration in provincial bodies. By 1911 they had belonged to the governor. And by tsar's decree from March 14, 1911, zemstvo self-government was introduced in the Right-Bank Ukraine: zemskyi bodies, such as: district and provincial zemstvo assemblies and administrations were elected. The election of zemtsies was a catalyst for a social and political life, broadened the range of public initiative showing and directed it into a single mechanism.

Elections and activity of zemstvos were covered in the press. Provincial press of a moderate-liberal direction «Kievlianin» being published in 1864-1919, is a powerful source of information about the activity of zemstvos in the territory of Kyiv province. Since 1890 this newspaper circulation had reached 5000 copies and it was one of the most popular newspapers in the Russian Empire, the information published therein had a wide range of distribution. The materials on the provincial zemstvo and district zemskyi authorities were published on the pages of «Kievlianin». Among the 12 districts of Kyiv province, Uman district was the second largest district by the population and the third largest district by the area. Consequently, it was one of the largest ones, determining the choice of geographical boundaries of our research.

Research analysis. The historiography of the zemstvos' activity cannot be considered insufficient. In its arsenal, it includes fundamental developments of zemstvos' history. To a greater extent, zemstvos are studied using a state material (Tykhonov, 1907) and several-volume works were prepared (Veselovskyi, 1909). Even such summarized editions as, for instance, «The Short Encyclopedia of Zemskyi Affairs in its Historical Development» was published (Rusov, 1914). 
The history of zemstvos in the territory of Ukraine is also studied by modern scholars (Mykolaienko, 2003). A cultural and educational activity of zemskyi institutions in Ukraine (Huz, 1997), zemstvo's support for peasant cooperations (Sulyha, 2002), an agropropaganda as an important link in zemstvo's activity (Sulyha, 2000), and the struggle of zemskyi institutions for the implementation of the Ukrainian language at primary schools (Huz, 2011), the empowerment of zemskyi authorities in the management of the public school in the late nineteenth and early twentieth centuries (Zakharova, 1999), zemskyi medicine in Ukraine (Stupak, 2009), questions about the extension of zemsky self-government to the Right-Bank Ukraine (Sulyha, 1999) are of considerable interest to researchers. An electoral zemstvo is not distinguished from a general history of zemstvos (1911-1920) and there is a lack of research interest in the coverage of the elections to zemstvos.

The aim of the article. On the basis of publications about Uman district zemstvo in 1911-1919, taken from the newspaper «Kievlianin», we are to cover the procedure of zemskyi elections and show the financial possibilities of zemstvos for improving the economic situation and the development of a cultural sphere of the life of population.

The main material. At the end of April in 1911, the newspaper «Kievlianin» reported that all district administrations for agricultural affairs of Kyiv province had completed the formation of zemskyi electoral lists and submitted them to the governor. According to the list from the Uman district, the number of voters was 973, among them: «Russian landowners - 97, Polish landowners - 99, trade and industrial enterprises -7 , Russian voters owning property from $1 / 5$ to full tsenz - 291, the same Polish voters- 67, Russian voters who own property from 1/5 to full tsenz - 394 and the same Polish voters - 18... (K voprosu, 1911: 413). On May 1, 1911, the electoral lists were printed out, and on May 16, the «Kievlianin», published the information on the number of zemskyi voters in each district province, in accordance with the article of the Third Imperial Decree from March 14, 1911. In Uman district it was possible to elect 39 zemskyi voters, «... including from the electoral assembly - 
26 (21 Russians and 5 Poles) and from rural societies - 13; provincial zemskyi voters - 7 (6 Russians and 1 Pole) ...» (Chyslo hlasnыkh, 1911: 3).

In accordance with the document regulating zemskyi elections from March 14, 1911, the full land qualification in Uman district for the participation in the zemsto's elections was considered to be the possession of a land plot of at least $621 / 2$ des., which was subject to the Zemsky levy. The value of other real estate was the same for all districts of Kyiv province. There were 203 persons with full qualifications in the Uman district, among whom there were: «... 97 Russians, 99 Poles and 7 commercial and industrial enterprises (Chyslo hlasnыkh, 1911: 3). On the whole, 120228 des. of land belonged to landowners: «Russians owned 50221 des., Poles - 69807 des. and commercial and industrial enterprises - 200 des. (Chyslo hlasnыkh, 1911: 3). Other real estate property of the land owners was valued at 5591407 rubles, among which 382225 rubles was the value of property of «Russian voters», 473450 rubles. - of Poles and 4735730 rubles. - of trade and industrial enterprises.

The largest land territories in Uman district were owned by: princess O. P. Dolhorukova - 19012 des. (Talne, Hlybochok, Lashcheva), P. I. Tereshchenko - 2 845 des. (Ladyzhynka, Khrystynivka, Shukayvoda, Sychivka), Ye. I. Tereshchenko 1916 des. and M. I. Tereshchenko - 1916 des. near these villages, Count A. M. Shuvalov - 1721 des. (Tekucha), baron M. I. Corf - 1603 des. (Synytsia, Kuzmyna Hreblia and Ositna), Baron F. Ye. Meiiendorf - 1635 des. (Yahubets). Regarding other real estate of the land owners of Uman district, these were: K.V. Yehorova, whose real estate was valued at 76000 rubles. and Ye. I. Maksymchyk whose property was valued at 53000 rubles (Chyslo hlasnыkh, 1911: 4).

In Uman district Polish landowners owned the following territories: S. V. Pidhorskyi - 13116 des. (Podvysoke, Nebelivka), I. Ye. Zhurovskyi - 5474 des. (Zelnkiv, Maidanetske), O. O. Ivanskyi - 2631 des. (Cherpovody, Ryzhavka), D. Ya. Rusetskyi - 3427 des. (Penozhkovo, Rohy), V. V. Lipkovskyi - 1993 des. (Horodnytsia), princes R. E., O. E. and E. E. Sviatopolk - Chetvertinski were the owners of land on 1833 des. each (Perehonivka, Kopenkovata, Rohova), I. F. Yelovitskyi - 1878 des. (Maksymivka, Liubashivka, Yurkivka) and A. M. 
Dzevanovskyi owned 1715 acres of land near the villages Antonivka and Buky. Concerning the Poles being the owners of other real estate, Yu. Yu. Hulianytskyi's property was valued at 60,000 rubles and O. K. Zhurakovskyi's property was valued at 75,500 rubles. Other Polish landowners had less property (Chyslo hlasnukh, 1911: $4)$.

According to the property value of institutions, unions, societies and companies, their land properties occupied only 200 des., which belonged to the Talne rural specialized school. But their other real estate was valued at much higher sums. Therefore, the buildings of the Udytskyi sugar factory were valued at 1200000 rubles (village Pohorila), the company of the Verkhnyatskyi sugar factory - at 921 600 rubles (village Verkhniachka), the company of the Kislinsk sugar factory - at 763200 rubles (village Kyslyn), the company of the sugar factory «Sviatopolk» - at 725000 rubles (village Perehonivka), Ivankiv sugar factory - at 603570 rubles (the village Ivanka), the Maidanetskyi sugar factory - at 522360 rubles (village Maidanetske).

The second category of voters included the land owners of the leased land area less than 62 1/2 des., but not less than 12 1/2 des. or other real estate, which was valued at 1500-7500 rubles. The list of voters of this category consisted of 357 people, among them: «Russians - 290, Poles - 67» (K vыboram, 1911: 4). The total area of land owned by such voters was 4132 des. Some of the voters of this category owned other real estate, the total value of which was 668266 rubles. The presence of land and other real estate in the above proportions ensured the right to vote in the zemskyi elections of 153 more persons, among them there were: «119 Russians, 34 Poles». There were 65 people owning the land, 88 people owning the other estate property (Chyslo hlasnыkh, 1911: 4).

The third category of voters included the owners of the leased land, the area of which was less than 12 1/2 des., but not less than 6 1/2 des., or owners of other real estate valued from 750 to 1500 rubles. In the lists there were 412 such voters, including: «394 Russians, 18 Poles» (Chyslo hlasnыkh, 1911: 4). Such persons owned 2322 des. of land, and the value of other real estate included in the lists of 
voters of the third category was valued at 112774 rubles. Owners of land and real estate could receive 53 votes in such proportions, among which: «51 votes belong to Russians and 2 votes to Poles» (Chyslo hlasnbkh, 1911: 4). According to qualifications, these votes are divided as follows: for land -36 , for other real estate 17.

Before the election of Uman district zemstvo there was a meeting of «Russian voters» in the amount of 44 people. The meeting was held at the premises of the zemskyi administration on May 14, 1911. Professor V. Ye. Chernov chaired the meeting. In his speech, he explained the peculiarities and advantages of elective zemstvos. He noted that the new zemstvo law from March 14, 1911 significantly expanded the rights of peasants, clergymen and clergymen of Christian confessions, owners of trade and industrial establishments concerning their participation in local government elections, which was not provided by zemstvos's regulation from June 12, 1890. The most debatable part of a new law is the norm about: «the division of voters into curiae - Russian and Polish» (K vvedenyiu, 1911: 3). Summarizing the thoughts of the speakers, professor V. Ye. Chernov summarized: «... recognizing the Polish curia, we thereby gave the Poles the right of self-determination, formed a kingdom in a kingdom; the others saw a deliberate desire to maintain the historical struggle that took place in western Russia between us and the Poles for the dominance of not only a state power, but also for the hegemony of culture of one nation over another in this division» (K vvedenyiu, 1911: 3). Concerning the attitude of the Poles themselves to the curial system, their dissatisfaction was based on, according to V. Ye. Chernov, that the law from March 14, 1911 undermined the influence of their wealth, culture, political unitedness concerning the life of the population of the Ukrainian Right Bank. The political influence of the Polish element weakened the new zemstvo law.

The complexity of zemstvo's work and its connection with public and administrative life were also discussed during the meeting. Not everyone could perform the duties of public service, a chairman V. Chernov emphasized in his speech, the duties could be performed only: «by people of strong will and great work, 
by people full of feelings of civilian dignity and duty, by honest people ...» (K vvedenyiu, 1911: 3). On the initiative of the chairman of the assembly, an organisation committee was elected for the Zemskyi elections, which was composed of prof. V. Ye. Chernov, the leader of the nobility of Uman district, Yu. F. Maiiendorf, Yeliseiev, Veselii, Maksymchyk, Kostenko, Sliusarenko (K vvedenyiu, 1911: 3).

The new law on the zemskyi elections from March 14, 1911 provided for the participation of the wealthy peasantry. The newspaper «Kievlianin» from June 15, 1911 reported that in all twenty districts of the Kyiv province there were elections of disrict zemskyi votels from rural societies. 140 zemskyi voters were elected from the peasants, 13 of which - in Uman district. In the rural communities of the district such people were elected: Oleksandr Tkachuk, Protasii Podlazhniuk, Yefrem Palamarchuk, Petro Donchuk, Panteleimon Bryzhatiuk, Makar Bazylskyi, Vasil Zobeida, Serhii Pastushenko, Dmitrii Gulko, Vasily Panchenko, Vasilii Gribyry, Vasili Pobur, Vasily Gubyry, Hryhorii Slupitskyi and Kuzma Khlystun.

After the publication of the lists of Zemsky voters from all over the Kyiv province, the governor announced the election dates and congresses he had set, and the places of their holding in each county. Under the head of the district nobility leaders, the election of zemskyi voters in Uman district was to be held in the military barracks of the village Mankivka in the following terms: the first election congress of the first department on July 12, the second department on July 14; the second election congress of the first department - on July 9, the second department - on July 7; the electoral assembly of the first department - on July 17, the second department - on July 20 (Vыborы, 1911: 3). A total number of Zemsky voters in Kyiv province was 12333 persons, among which 1840 persons had full qualification and 10493 persons had not. By national composition: among the Russian owners of land there were 1,151 persons and Poles -645 persons. In addition, the full-fledged were 44 trade and industrial enterprises, from which authorized persons participated in the election. It was stipulated that if an authorized person is of «Russian origin», then he will realize 
his voting right in the first polling station, and if he is a Pole, then during elections he will take place in the second division of the same assembly.

A total number of incomplete voters - 10493 persons - included 9393 persons of «Russian origin». Underage voters were divided into two categories: odnopiatnyks and odnodesiatnyks. There were 3,928 odnopiatnyks and 10,665 odnodesiatnyks.

In Uman district, a total number of voters was 955, of which 200 were land owners and 755 were not land owners. According to nationality, 95 persons were of Russian origin and 98 were Polish. Among odnopiatnyks there were 345 (281 Russians and 64 Poles) and there were 410 odnodesiatnyks (392 Russians and 18 Poles) (K zemskykh vыboram, 1911: 2-3).

Telegrams from the districts about the course of zemskyi elections were published on the front pages of the provincial newspaper «Kievlianin». From Uman on July 7, it was reported that the congress of odnodesiatnyks of the Polish curia had not been held at the appointed time due to the absence of voters. The newspaper reported on July 10 that the congress of the odnodesiatnyks of Russian origin had not taken place either, as only 6 land censors and 2 non-land censors appeared at the appointed time (Vыborы v Kyevskoi hubernyy, 1911: 3). On July 13, the newspaper reported that on July 12,1911, the election of zemskyi commissioners in five districts took place. In Uman district, there were 24 persons who elected 10 voters to the congress of Russian origin (Zemskye vыborы upolnomochennыkh, 1911: 3).

According to sources, commissioners from the Polish curia often sabotaged zemskyi elections. Thus, on July 14, 1911, the elections of commissioners of the Poles in Kyiv, Vasylkiv, Uman, Cherkasy and Chyhyryn districts were appointed. None of these congresses were held because voters did not gather (Vыborы, 1911: 3). Yet the election of the Zemskyi voters was held. On July 19, 1911, the Kyiv-based provincial newspaper reported the election results in the Russian constituency of voters in Uman district. Zemskyi voters from the full-fledged were selected: honorary citizen (the landowner is the author.) Drawer, a nobleman I. A. Steinberg, a leader of the nobility of the Uman district Baron Yu. Kryzhanovsky, prince S. O. Dogorukyi, A. K. Feshchenko, peasant Prityka, E. G. Poberezets, a peasant Naumenko, a 
nobleman Popandopulo, a nobleman Chepurkovskyi, L. F. Papirovoy, honorary citizen P. M. Domansky; from odnopiatnyks - a nobleman Domanitsky, a peasant Zozulya and a nobleman M. M. Kovesnikov (Zemskye vыborы hlasnykh, 1911: 3).

The last stage of the election process of the Uman district zemstvo was the extraordinary assembly of elected district voters, at which the zemstvo government and provincial voters were elected. The meeting took place on July 30, 1911, under the chairmanship of the county leader of the nobility, Yu. F. Meiiendorf. A ceremonial part of the meeting was a thank-you prayer and the swearing-in of the elected district voters: Orthodox in the city council, Catholic Poles in the premises of the district council. The greeting word of the chairman was read out and the telegram text was read to the emperor. V. Ye. Chernov, noting the active assistance in the formation of zemstvos in the Southwestern region of the empire of Minister of Internal Affairs P. A. Stolypin, offered to send him a thank you telegram. But the Polish vowel speaker A. M. Dzevanovskyi opposed such a proposal. And not because the Poles were against zemstvos, but because: «they are unpleasant and unbearable to the intolerance of the Zemsky law in the part where it is said that Zemsky voters are divided into Russian and Polish curiae» (Chrezvыchainoe sobranye, 1911: 3).

The Provincial Assembly, as the elected local self-government body with administrative functions, elected the zemskyi district administration of the Uman district - the body with executive functions. The chairman of the board was Yu. F. Meiiendorf, who was already known in the zemskyi circles since the introduction of Zemstvo in the Right-Bank Ukraine, and at that time he was the leader of the nobility of Uman district. The following members of the Zemsky district government were elected: O. Ye. Yeliseiev, L. V. Kostenko and P. M. Domanitskyi. The provincial voters elected: A. K. Feshchenko, V. Ye. Chernova, S. A. Dovhorukyi, N. Ye. Yashchyk, I. A. Shteinberg, from the peasants - D. Ye. Hulko and from the Polish Curia - D. Ivanskyi (Chrezvыchainoe sobranye, 1911: 3). The composition of Uman district zemstvos was approved by the Kyiv governor on August 12, 1911. Thus, according to the law on zemstvos from March 14, 1911, elected local selfgovernment bodies - the Zemskyi assembly (administrative functions) and the 
Zemsky executive for a term of three years. Subsequently, the composition of the Zemsky voters and members of the county council changed, but its head Yu. F. Meiiendorf remained almost unchanged until the elimination of zemstvos. Zemstvo activity was terminated by a decree of the Soviet government in Ukraine from January 22, 1920. But according to a well-known public figure P. F. Kurinnyi, the Uman district zemstvo was dissolved by the Denikin authorities in early November in 1919 (Uman, 2015: 104).

Although district zemstvos had a wide field of activity, but one of the priority areas was to promote agriculture. Zemstvo hired agronomists, veterinarians, wrote and organized the sale or rental of agricultural machinery and equipment, opened breeding stations and breeding points. In order to improve the agro-culture of the peasants, the Zemstvo organized agricultural exhibitions and awarded the best exhibits. Only the list of reports of the Uman Zemstvo Administration at the district assembly of Zemsky vowels in 1912 provides an idea of the breadth of Zemstvo activity in the direction of agricultural development. In particular, the following issues were discussed: agricultural machinery rental points; measures to improve livestock development in the district; opportunities for beekeeping and silk production; on raising salaries for representatives from peasants in the Uman district agricultural council, etc. (Dokladы Upravы, 1913: 60).

Zemstvo was aimed at creating favourable economic conditions for the local population, promoting the raise of the peasant and local economy, stimulating the development of cooperation, handicraft and industrial production in the country. The success of Uman Zemstvo in the development of the cooperative movement was especially recognized. On January 1, 1916, the «Kievlianin» reported that: «... Uman district, by the number of cooperatives of all kinds, occupies one of the first places in our province, and by the activity of some of them far leaves behind all without exception the district» (Kievlianin, 1916: 4). There were about 70 consumer cooperatives in Uman district alone, all of them were established within 15-16 years since it first emerged in 1899 in the village. Dzengelivka. Subsequently, the consumer cooperatives of the county were organized into a single union, forming the 
Zemsko-Cooperative Purchasing Association of the Uman District, the purpose of which was to establish purchase prices and combat speculation. The Uman district zemstvo joined this union by paying an entry fee of 1,000 rubles. while the contributions of other members did not exceed 200 rubles.

The Kyiv newspaper reported that other types of cooperatives, including credit ones, have become widespread in the Uman district. On January 1, 1916, there were 25 credit cooperatives in the district - 18 loan savings banks and 7 loan companies, and the largest was named Talnivskyi Credit (3,000 members) and Dzengelivske Loan Companies (7,000 members). The first of them conducted a wide brokerage operation, for which he built a large and well-equipped elevator, which became the first in the Kyiv province. The Dzengel Cooperative Society has had an annual turnover of millions of dollars, developing various activities, in particular: sale of products of its shareholders, intermediary trade in agricultural machinery and stock, metal, grain, etc.

And another type of cooperatives were agricultural and handicraft societies. The most common cooperatives for the sale of dairy products and eggs were dairy and egg artels. The first egg artel in Kyiv province appeared in the village Pidvysoke of Uman district. Due to the dairy and egg cooperatives that supplied the products mainly to Kyiv, the peasants were gradually getting rid of the buyers who were lowering their purchase prices and inflating the sale prices.

Zemstvo also took care of the construction of factories and warehouses necessary for the population. The correspondent of «Kievlyanin», outlining information about the meeting of Uman zemstvo on March 22-24, 1914, noted that the issue of construction in the district of the brick-tile factory was on the agenda (Kievlianin, 1914 (a): 3). The need for construction of the plant was explained by the fact that the demand for high quality and not expensive brick and tile increased among the rural population. Uman zemstvo raised before the government the issue of permission and grant of 2500 rubles with a repayment period of 15 years and began a construction work. In addition, zemstvo pledged that in the event of receiving a construction subsidy, will sell brick and tile at cost. 
At the same Zemsky meetings, the urgent need for the construction of a refrigeration warehouse in Uman and the slaughterhouses under it was discussed. A decision was made to prepare the project and the budget, as well as to initiate a petition before the provincial zemstvo to allocate a subsidy for the implementation of such an undertaking of the Uman Zemstvo. The district zemskyi government has allocated 4000 rubles for preparatory works.

The financial basis of zemstvo activity was a special zemsky estate tax. The amount of this tax has often been the subject of controversy and conflicts between zemstvo and city authorities. On March 17, 1912, a correspondent of the Kyiv City reported on a meeting of the city council in Uman, which considered the issue of excessive taxation of the city by land taxes. The city duma considered that the increase in taxes was not caused by an increase in the profitability of urban property, and therefore is a heavy burden for the city. «How large this tax is ... is evident from the following: in 1911 the tax burden reached 32002 rubles, and in 1912 it exceeded 55000 rubles» (Kievlianin, 1912 (a): 4). Taking into account such an increase of zemskyi tax, the city duma appealed to Uman district zemskyi assembly and submitted it to the governor. The complaint remained unaddressed as by the time of its receipt, the governor had already approved the resolution of the Uman county zemstvo assembly on the estimate of the zemstvo. Therefore, the city council had to appeal to the Uman Zemstvo requesting revision of the tax on urban real estate, but there was no hope for a positive decision of zemstvo.

The sympathies of the «Kievlianin» correspondent were on the side of the Uman city duma, as in his next note on the rejection of zemstvo's request by the city administration to reduce zemskyi levy, he wrote: «A young institution, such as our zemstvo, should listen carefully to all petitions, wherever they come from» (Kievlianin, 1912 (b): 4). He reasoned that the increase in the amount of tax for one year from 32 to 55 thousand to everyone, not even very aware of the city's revenues, would appear abnormal. Therefore, zemstvos needed to follow the city authorities' recommendations. 
The question of the excessive amounts of zemskyi real estate taxes was covered in the «Kievlianin» in 1915. In January 23, 1915 issue, it was reported that Uman district zemstvo, by subdividing by real estate category in the district the distribution of the land levy for 1912, adhered to the property value taxation system, besides, among other things, it overlaid the existing sugar factories in the district. When calculating for the next 1913, zemstvo applied a completely different system, namely: a system of taxation on the value and profitability of the enterprise. The board of the Maidanetskyi and Ryzhavskyi sugar factories appealed against a zemskyi decree, at first, in the provincial and city affairs, and then, when zemstvo did not agree with the arguments of the complaint, - to the Senate. The Senate's decision recognized the validity of the complaint and prohibited Zemstvo from calculating taxes under the new schemes (Kievlianin, 1915: 4).

The question concerning the formation of zemstvo's money fund was given a priority at each district zemstvo assembly. In April 1913 it was discussed in the context of formation of special funds. The correspondent of «Kievlianin» wrote that Uman zemstvo at the budget of 963 thousand rubles does not have working capital and therefore in case of need for funds it is compelled to apply to banks for loans, which is not entirely profitable. Government loans can only be obtained at the end of the year, which is also not profitable. Therefore, in order to regulate a financial issue, it is necessary to create three funds: school-building, road-building, property and civil structures (Kievlianin, 1913: 5). After an active discussion at the zemskyi assembly, the matter was referred to a special commission for a comprehensive study.

Traditionally, the funds for specific needs were taken in credit institutions, but after obtaining an appropriate approval. Consequently, in June 1914, the «Kievlianin» wrote that the Ministry of Internal Affairs approved a resolution of the Kyiv provincial zemstvo to allow the Uman district zemstvo to take a loan of 200,000 rubles for the construction of a house for zemsky institutions in Uman and another 200,000 rubles to finance the estimated costs of zemstvo (Kievlianin, 1914 (b): 3). In December 1914, the Uman County Zemstvo was given a loan in the State Treasury for 124,000 rubles (Kievlianin, 1914 (c): 5). 
The realization of tasks and authorities of zemstvos required considerable financial costs. The basis for the formation of zemsky capital was zemsky collection of real estate property. The financial opportunities of zemstvo are made up of the reports of Uman district zemstvo administration about zemstvo's income and expenses, which were compiled at the beginning or at the end of the year. The report covered the balance of land funds in detail by all items of expenditure and from all income sources, but the use of the land levy was analyzed profoundly (Denezhnыi otchet, 1915: 232). In addition, the Uman land levy was published (Zemskyi Sbor, 1915: 221), which covered a financial potential of zemstvo. As for the property of the Uman Zemstvo itself, it consisted of: Uman arrest house, 35 zemskyi schools in district, 6 zemskyi hospitals, a demonstration khutir «Synytsia», a model farm in the village Kuzmyna Hreblia, a demonstration khutir in the village Pokotylove, an agronomic estate in Torhovytsi, a telephone station in Tomashivka, land territories under schools in Korsunets, Krachkivka, Oksanino, Okhmatov, Pavlovka and under the hospital in Buky, under the Zemstvo Office in Uman, under a model farm in Osytnia. A total value of a zemstvo's real estate was 10071010 rubles. And the real estate of Uman Zemstvo was: visual aids and accessories of 35 zemskyi schools and 34 zemskyi specialized schools, equipment of zemskyi hospitals, dispensaries, veterinary stations. The maintenance and functioning of zemskyi property was provided by means of zemskyi funds.

Conclusion. So, the articles published in the newspaper «Kievlianin» and systematized publications about Uman district zemstvo give a clear idea about the mechanism of the zemskyi elections based on the law from March 14, 1911. Information concerning voters' property qualification enlarges land ownership statistics in Uman district and gives an idea about the financial opportunities of some industrial enterprises, associations, companies. The division of voters by property qualification into three categories and the division by nationality into Russian and Polish curiae show a discriminatory nature of the electoral process. Even a legal participation of a wealthy peasantry in the elections did not give them the opportunity to be elected to local self-government bodies: in general, in the «peasant» Uman 
district 13 people were elected to the zemskyi authorities, while in the «peasant» Kyiv province -140 peasants. Therefore, declaring their omnipotent nature, zemstvos helped activate the activity of liberally minded middle-class and wealthy people. Being provided with a state support and owing to a partial financing of their activity, zemskyi authorities, using the land tax method, formed their own funds in order to stimulate agriculture, peasant cooperation, handicraft and industrial production, and a socio-cultural needs of the population.

A collected and systematized material in the article enlarges a source base of zemstvos and a regional history. Further research prospects are based on a complex study of the newspaper «Kievlianin» as a source of the history of zemskyi institutions in the Right-Bank Ukraine in the second half of the 19th - the early 20th centuries.

\section{REFERENCES}

Veselovskyi, 1909 - Veselovskyi B. B. Ystoryia zemstva za sorok let [History of Zemstvo for forty years]: V 4 tomakh. SPb., 1909. [in Russian]

Vыborы, 1911 - Zemskye vыborы v Kyevskoi hubernyy [Zemsky elections in the Kiev province]. Kyevlianyn, 1911, №193, s. 3. [in Russian]

Vыborы v Kyevskoi hubernyy, 1911 - Zemskye vыborы v Kyevskoi hubernyy [Zemsky elections in the Kiev province] // Kyevlianyn. 1911. №188. S. 3. [in Russian]

Huz, 1997 - Huz A. M. Kulturno-osvitnia diialnist zemskykh ustanov v Ukraini (1864-1914 rr.) [Cultural and educational activity of Zemsky institutions in Ukraine (1864-1914)]: avtoref. dys. ... kand. istor. nauk: 07.00.01. Kyiv, 1997. 24 s. [in Ukrainian]

Huz, 2011 - Huz A. Borotba zemskykh ustanov Ukrainy za vprovadzhennia u pochatkovi navchalni zaklady ukrainskoi movy u druhii polovyni XIX - na pochatku XX st. [The struggle of the Zemsky institutions of Ukraine for the introduction into the primary educational institutions of the Ukrainian language in the second half of the nineteenth and early twentieth centuries.] // Universytet. 2011. № 5. S. 63-68. [in Ukrainian]

Zakharova, 1999 - Zakharova I. V. Rozshyrennia prav zemskykh orhaniv v upravlinni narodnoiu shkoloiu (druha polovyna XIX - pochatok XX st.) [Expansion of the rights of Zemsky Authorities in the Management of the Public School (second half of XIX - beginning of XX century)] // Visnyk Cherkaskoho universytetu. Seriia: istorychni nauky. 1999. Vyp. 12. S. 90-94. [in Ukrainian]

Zemskye vыborы, 1911 - Zemskye vыborы v Kyevskoi hubernyy [Zemsky elections in the Kiev province] // Kyevlianyn. 1911. №169. S. 3. [in Russian]

Zemskye vыborы hlasnykh, 1911 - Zemskye vыborы hlasnыkh v Kyevskoi hubernyy [Zemsky Vowels elections in the Kiev province] // Kyevlianyn. 1911. №197. S. 3. [in Russian]

Zemskye vыborы upolnomochennыkh, 1911 - Zemskye vыborы upolnomochennыkh v Kyevskoi hubernyy [Zemsky election of commissioners in the Kiev province] // Kyevlianyn. 1911. S. 3. [in Russian]

Zemskyi Sbor, 1915 - Umanskyi Zemskyi Sbor [Uman Zemsky Sbor]. Uman, 1915. 221 s. [in Russian]

Denezhnыi otchet, 1915 - Denezhnыi otchet Umanskoi Uezdnoi Zemskoi Upravы za 1914 h. [Monetary Report of Uman District Land Administration for 1914 Uman], 1915. 232 s. [in Russian]

Dokladы Upravы, 1913 - Dokladы Upravы Umanskomu Ocherednomu Zemskomu sobranyiu, sozыva 1912 hoda [Reports of the Board of the Uman Regular Zemsky Assembly, convened of 1912]. Uman, 1913, 60 s. [in Russian]

$\mathrm{K}$ vvedenyiu, 1911 - K vvedenyiu vbboronoho zemstva [To the introduction of the elected Zemstvo]. Kyevlianyn, 1911, №135, s. 3. [in Russian]

K voprosu, 1911 - K voprosu o vvedenyy vыbornoho zemstva [To the Question of the Introduction of Elective Zemstvo] // Kyevlianyn. №114. 1911, S. 413. [in Russian]

K vыboram, 1911 - K vыboram uezdnыkh zemskykh hlasnыkh ot selskykh obshchestv Kyevskoi hubernyy [By the election of district zemskyi voters from rural societies of Kyiv province] // Kyevlianyn. 1911. №163. S. 4. [in Russian] K zemskykh vыboram, 1911 - K zemskykh vыboram v Kyevskoi hubernyy [To the Zemstvo elections in the Kiev province] // Kyevlianyn. 1911. №182. S. 2-3. [in Russian]

Kyevlianyn, 1912 (a) - Kyevlianyn. 1912. №77. S. 4. [in Russian] 
Kyevlianyn, 1912 (b) - Kyevlianyn. 1912. №129. S. 4. [in Russian]

Kyevlianyn, 1913 - Kyevlianyn. 1913. №99. S. 5. [in Russian]

Kyevlianyn, 1914 (a) - Kyevlianyn. 1914. №90. S. 3. [in Russian]

Kyevlianyn, 1914 (b) - Kyevlianyn. 1914. №190. S. 3. [in Russian]

Kyevlianyn, 1914 (c) - Kyevlianyn. 1914. №352. S. 5. [in Russian]

Kyevlianyn, 1915 - Kyevlianyn. 1915. №23. S. 4. [in Russian]

Kyevlianyn, 1916 - Kyevlianyn. 1916. №1. S. 4. [in Russian]

Mykolaienko, 2003 - Mykolaienko I. M. Istoriohrafiia diialnosti zemskykh ustanov Ukrainy (1864-2001) [The historiography of the activity of Zemskyi institutions of Ukraine (1864-2001)]: avtoref. dys. ... kand. istor. nauk: 07.00.01. Kyiv, 2003. 20 s. [in Ukrainian]

Rusov, 1914 - Rusov A. A. Kratkaia эntsyklopedyia zemskoho dela v eho ystorycheskom razvytyy [A brief encyclopedia of Zemstvo affairs in its historical development]. Kyev, 1914. 119 s. [in Russian]

Stupak, 2009 - Stupak F. Zemska medytsyna v Ukraini [Zemsky medicine in Ukraine] // Istorychnyi zhurnal. 2009. №5. S. 61-74. [in Russian]

Sulyha, 1999 - Sulyha I. H. Do pytannia pro poshyrennia zemskoho samovriaduvannia na Pravoberezhnu Ukrainu [On the question of the extension of zemskyi self-government to the Right-Bank Ukraine] // Naukovyi visnyk Izmailskoho derzhavnoho pedahohichnoho instytutu. Izmail. 1999. Vyp. 7. S. 14-19. [in Ukrainian]

Sulyha, 2000 - Sulyha I. H. Ahropropahanda - vazhlyva lanka diialnosti zemstv Pravoberezhnoi Ukrainy ta Bessarabii [Agropropaganda - an important link in the activity of zemstvos of the Right-Bank Ukraine and Bessarabia] // Naukovyi visnyk Izmailskoho derzhavnoho pedahohichnoho instytutu. Izmail. 2000. Vyp. 9. S. 37-41. [in Ukrainian]

Sulyha, 2002 - Sulyha I. H. Zemstva i selianska kooperatsiia v Pravoberezhnii Ukraini na pochatku XX st. [Zemstvos and peasant cooperation in the Right-Bank Ukraine at the beginning of the XX century] // Ukrainskyi selianyn. Cherkasy. 2002. Vyp. 5. S. 59-61. [in Ukrainian]

Tykhonov, 1907 - Tykhonov T. Y. Zemstvo v Rossyy y na okraynakh [Zemstvo in Russia and on the outskirts]. SPb., 1907. 150 s. [in Russian]

Uman, 2015 - Uman ta umanchany ochyma P. F. Kurinnoho [Uman and Uman residents in the vision of P. F. Kurinnyi]. 2015. s. 104. [in Ukrainian]

Chrezvыchainoe sobranye, 1911 - Chrezvыchainoe zemskoe sobranye v Umanskom uezde [Extraordinary Zemstvo Assembly in Uman County] // Kyevlianyn. 1911. №212. S. 3. [in Russian]

Chyslo hlasnыkh, 1911 - Chyslo hlasnыkh uezdnыkh y hubernskykh zemskykh sobranyi v Kyevskoi hubernyy [The number of vowels of county and provincial assemblies in the Kiev province] // Kyevlianyn. 1911. №134. S. 3. [in Russian] 